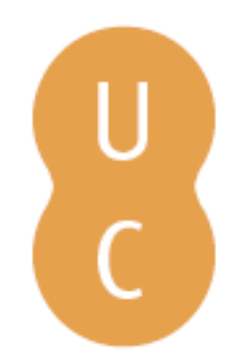

\title{
nombalina
}

\section{Development and application of wildfire suppression expenditure models for decision support and landscape planning}

Autor(es): $\quad$ Hand, Michael S.; Thompson, Matthew P.; Calkin, David E.

Publicado por: Imprensa da Universidade de Coimbra

URL

persistente: URI:http://hdl.handle.net/10316.2/34297

DOI: $\quad$ DOI:http://dx.doi.org/10.14195/978-989-26-0884-6_149

Accessed : $\quad$ 26-Apr-2023 06:23:30

A navegação consulta e descarregamento dos títulos inseridos nas Bibliotecas Digitais UC Digitalis, UC Pombalina e UC Impactum, pressupõem a aceitação plena e sem reservas dos Termos e Condições de Uso destas Bibliotecas Digitais, disponíveis em https://digitalis.uc.pt/pt-pt/termos.

Conforme exposto nos referidos Termos e Condições de Uso, o descarregamento de títulos de acesso restrito requer uma licença válida de autorização devendo o utilizador aceder ao(s) documento(s) a partir de um endereço de IP da instituição detentora da supramencionada licença.

Ao utilizador é apenas permitido o descarregamento para uso pessoal, pelo que o emprego do(s) título(s) descarregado(s) para outro fim, designadamente comercial, carece de autorização do respetivo autor ou editor da obra.

Na medida em que todas as obras da UC Digitalis se encontram protegidas pelo Código do Direito de Autor e Direitos Conexos e demais legislação aplicável, toda a cópia, parcial ou total, deste documento, nos casos em que é legalmente admitida, deverá conter ou fazer-se acompanhar por este aviso.

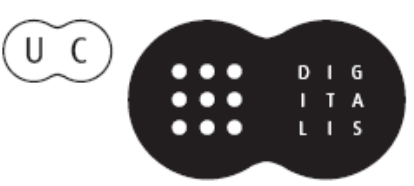




\section{ADVANCES IN}

Forest Fire

\section{RESEARCH}

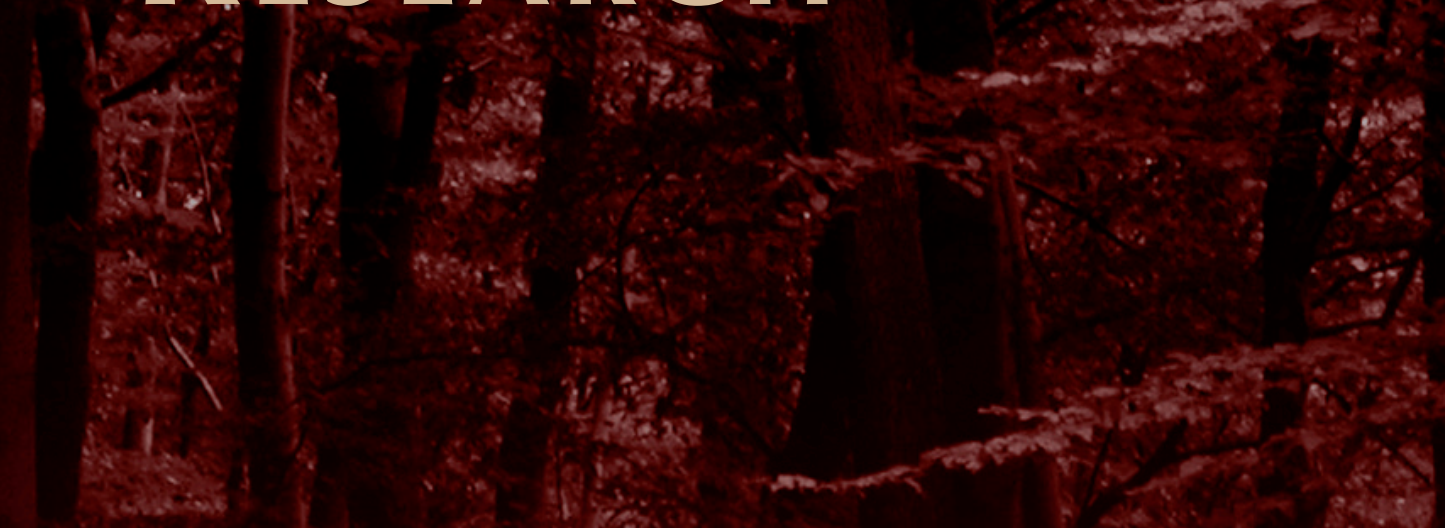

\section{DOMINGOS XAVIER VIEGAS}

\section{EDITOR}




\title{
Development and application of wildfire suppression expenditure models for decision support and landscape planning
}

\author{
Michael S. Hand ${ }^{a}$, Matthew P. Thompson ${ }^{\text {a }}$, David E. Calkin ${ }^{\mathrm{a}}$ \\ ${ }^{a}$ US Forest Service Rocky Mountain Research Station, Missoula, Montana, USA, mshand@fs.fed.us, \\ decalkin@fs.fed.us, and mpthompson02@fs.fed.us
}

The opinions expressed in this paper are the authors' and do not necessarily reflect the views of the U.S. Department of Agriculture

Keywords: suppression expenditures; spatial models; decision support; fuel treatments

\section{Extended abstract}

A major consequence of large wildfires is the budgetary impact on public agencies tasked with wildfire management and suppression efforts. In wildfire seasons with a high incidence of large and expensive fires, agency budgets for non-fire activities can be threatened when the immediate needs of wildfire management are prioritized. In the United States, wildfire management already accounts for a large and increasing share of the U.S. Forest Service's (USFS) budget, which strains other land management needs. Between 1992 and 2011, the annual budget dedicated to fire management grew from 13 to over 40 percent of total agency appropriations.

This extended abstract describes the development of expenditure models that are capable of providing spatially and temporally explicit information about costs, and provides examples of how such models can complement sophisticated fire simulation models used to support incident management decisions and landscape-scale fire planning. To date, expenditure modelling efforts have yielded insights into the geographic, landscape, socio-political, and management characteristics associated with wildfire suppression expenditures. These insights are based on models that relate characteristics associated with the location and date of ignition of wildfires to expenditure records (e.g., Gebert et al. 2007; Gude et al. 2013; Donovan et al. 2011; Yoder and Gebert 2012). However, decision support tools and wildfire modelling efforts increasingly use detailed spatial and temporal descriptions of geographic, landscape, and weather conditions. Accounting for heterogeneity of such conditions in management expenditure models may improve link between fire modelling outputs and expenditure models for fire management planning and decision support.

Incorporating spatial characteristics in expenditure models has limited precedent in the literature. Priesler et al. (2011) create spatially explicit forecasts of expenditures, but the underlying expenditure model is based on ignition-point data. Liang et al. (2008) incorporated spatial characteristics of the area within fire perimeters to account for observed spatial autocorrelation of expenditures for limited set of fires in the Northern Rockies region of the United States. Hand et al. (2014, ch.4) extend the approach in Liang et al. (2008) to include fires in the entire Western United States, but did not evaluate the role of heterogeneity or assess model performance relative to ignition-point models. The data and methods in Hand et al. (2014) form the basis of the empirical models in this paper.

To develop spatially and temporally descriptive expenditure models, final fire perimeters were gathered for a sample of large fires (greater than 121 hectares) from the western United States. In total, 406 fires from fiscal years 2006 to 2011 are used in the final estimation sample. The fire perimeters were used in conjunction with several geo-spatial data layers to describe the extent and variation of geographic and landscape characteristics that are thought to be associated with expenditures. The time period between the discovery date of the fire and the date of control or containment was used to examine landscape and geographic characteristics within the fire perimeter that may vary over time. 
The spatially and temporally descriptive characteristics are used as independent variables in a regression model to predict total incident expenditures by Federal management agencies. ${ }^{1}$ Table 1 describes the variables used in the regression model and the corresponding variables in ignition-point expenditure models that the spatially and temporally descriptive variables replace.

Table 1. Variables used in spatially descriptive regression with corresponding ignition-point variables; obs. $=406$

\begin{tabular}{|c|c|c|c|}
\hline Variable & Description & $\begin{array}{l}\text { Source (see table } \\
\text { footnote) }\end{array}$ & $\begin{array}{l}\text { Corresponding ignition- } \\
\text { point variables }\end{array}$ \\
\hline $\ln \exp$ & $\begin{array}{l}\text { Natural log of total federal suppression } \\
\text { expenditures in constant } 2012 \$ \text { (Dep. Var.) }\end{array}$ & FFIS & -- \\
\hline lnacres & $\begin{array}{l}\text { Natural log of area within final fire } \\
\text { perimeter }\end{array}$ & NIFC FTP & -- \\
\hline erc_max & $\begin{array}{l}\text { Maximum relative ERC percentile observed } \\
\text { during the fire within the final perimeter }\end{array}$ & $\begin{array}{l}\text { GIS calculation of } \\
\text { data from } \\
\text { Abatzoglou (2011) }\end{array}$ & $\begin{array}{l}\text { ERC at ignition point and } \\
\text { time }\end{array}$ \\
\hline erc_std & $\begin{array}{l}\text { Standard deviation of relative ERC } \\
\text { observed during the fire within the final } \\
\text { perimeter }\end{array}$ & $\begin{array}{l}\text { GIS calculation of } \\
\text { data from } \\
\text { Abatzoglou (2011) }\end{array}$ & $\begin{array}{l}\text { ERC at ignition point and } \\
\text { time }\end{array}$ \\
\hline Inavelev & $\begin{array}{l}\text { Natural log of the average elevation within } \\
\text { the final perimeter }\end{array}$ & LANDFIRE & Elevation at ignition point \\
\hline wild_burn & Burned within Wilderness area (binary) & WFDSS & $\begin{array}{l}\text { Ignition within Wilderness } \\
\text { area (binary) }\end{array}$ \\
\hline wild_sh & $\begin{array}{l}\text { Share of final burned area within a } \\
\text { Wilderness area }\end{array}$ & WFDSS & $\begin{array}{l}\text { Distance of ignition point } \\
\text { from Wilderness boundary }\end{array}$ \\
\hline ira_burn & $\begin{array}{l}\text { Burned within an Inventoried Roadless } \\
\text { Area (binary) }\end{array}$ & WFDSS & $\begin{array}{l}\text { Ignition within Inventoried } \\
\text { Roadless Area (binary) }\end{array}$ \\
\hline$i r a \_s h$ & Share of final burned area within an IRA & WFDSS & $\begin{array}{l}\text { Distance of ignition point } \\
\text { from IRA boundary }\end{array}$ \\
\hline other_burn & $\begin{array}{l}\text { Burned within other specially designated } \\
\text { area (binary) }\end{array}$ & WFDSS & $\begin{array}{l}\text { Ignition within other } \\
\text { specially designated area } \\
\text { (binary) }\end{array}$ \\
\hline other_sh & Share of final burned area within a SDA & WFDSS & $\begin{array}{l}\text { Distance of ignition point } \\
\text { from SDA boundary }\end{array}$ \\
\hline slope1 & $\begin{array}{l}\text { Share of final burned area with slope less } \\
\text { than } 20 \% \text { (omitted reference category) }\end{array}$ & LANDFIRE & \multirow{5}{*}{$\begin{array}{l}\text { Percent slope at ignition } \\
\text { point }\end{array}$} \\
\hline slope2 & $\begin{array}{l}\text { Share of final burned area with slope } \\
\text { between } 20 \% \text { and } 40 \%\end{array}$ & LANDFIRE & \\
\hline slope3 & $\begin{array}{l}\text { Share of final burned area with slope } \\
\text { between } 40 \% \text { and } 60 \%\end{array}$ & LANDFIRE & \\
\hline slope4 & $\begin{array}{l}\text { Share of final burned area with slope } \\
\text { between } 60 \% \text { and } 80 \%\end{array}$ & LANDFIRE & \\
\hline slope 5 & $\begin{array}{l}\text { Share of final burned area with slope greater } \\
\text { than } 80 \%\end{array}$ & LANDFIRE & \\
\hline usfs_sh & $\begin{array}{l}\text { Share of final burned area in USFS } \\
\text { ownership }\end{array}$ & WFDSS & $\begin{array}{l}\text { USFS ownership at } \\
\text { ignition point (binary) }\end{array}$ \\
\hline doi_sh & $\begin{array}{l}\text { Share of final burned area in Dept. of } \\
\text { Interior ownership }\end{array}$ & WFDSS & $\begin{array}{l}\text { DOI ownership at ignition } \\
\text { point (binary) }\end{array}$ \\
\hline grass_sh & Share of final burned area with grass fuels & LANDFIRE & $\begin{array}{l}\text { Grass fuels at ignition } \\
\text { point (binary) }\end{array}$ \\
\hline brush_sh & Share of final burned area with brush fuels & LANDFIRE & $\begin{array}{l}\text { Brush fuels at ignition } \\
\text { point (binary) }\end{array}$ \\
\hline
\end{tabular}

${ }^{1}$ The sample of fires includes only fires managed primarily by the U.S. Forest Service. However, other Federal agencies may incur a minority of expenses for the management of these fires. The dependent variable represents total Federal expenditures. 


\begin{tabular}{|c|c|c|c|}
\hline timber_sh & Share of final burned area with timber fuels & LANDFIRE & $\begin{array}{l}\text { Timber fuels at ignition } \\
\text { point (binary) }\end{array}$ \\
\hline slash_sh & Share of final burned area with slash fuels & LANDFIRE & $\begin{array}{l}\text { Slash fuels at ignition point } \\
\text { (binary) }\end{array}$ \\
\hline Inhousein & $\begin{array}{l}\text { Natural log of housing value within the final } \\
\text { perimeter in constant } 2012 \$\end{array}$ & U.S. Census & ( \\
\hline Inhouse5_perim & $\begin{array}{l}\text { Natural log of housing value within } 5 \text { miles } \\
\text { of final perimeter in constant } 2012 \$\end{array}$ & U.S. Census & $\begin{array}{l}\text { Housing value within } 5 \mathrm{mi} \text {. } \\
\text { of ignition point }\end{array}$ \\
\hline Inhouse10_perim & $\begin{array}{l}\text { Natural log of housing value between } 5 \text { and } \\
10 \text { miles from perimeter in constant } 2012 \$\end{array}$ & U.S. Census & $\begin{array}{l}\text { Housing value within } 10 \\
\text { mi. of ignition point }\end{array}$ \\
\hline Inhouse20_perim & $\begin{array}{l}\text { Natural log of housing value between } 10 \\
\text { and } 20 \text { miles from perimeter in constant } \\
2012 \$\end{array}$ & U.S. Census & $\begin{array}{l}\text { Housing value within } 20 \\
\text { mi. of ignition point }\end{array}$ \\
\hline asp_123 & $\begin{array}{l}\text { Share of final burned area with North, } \\
\text { Northeast, or East aspect }\end{array}$ & LANDFIRE & \multirow{3}{*}{$\begin{array}{l}\text { Sine and cosine of aspect } \\
\text { (in radians) at ignition } \\
\text { point }\end{array}$} \\
\hline asp_456 & $\begin{array}{l}\text { Share of final burned area with Southeast, } \\
\text { South, or Southwest aspect }\end{array}$ & LANDFIRE & \\
\hline asp_78 & $\begin{array}{l}\text { Share of final burned area in West or } \\
\text { Northwest aspect (omitted reference } \\
\text { category) }\end{array}$ & LANDFIRE & \\
\hline duration & Fire duration in days, top-coded at 90 days & NIFMID & -- \\
\hline dur 2 & Square of duration & NIFMID & -- \\
\hline dur3 & Cubic of & NIFMID & -- \\
\hline reg_l 1 & $\begin{array}{l}\text { Northern region identifier (binary, omitted } \\
\text { reference category) }\end{array}$ & NIFMID & -- \\
\hline reg_2 & Rocky Mountain region indicator (binary) & NIFMID & -- \\
\hline reg_3 & Southwest region indicator (binary) & NIFMID & -- \\
\hline reg_4 & Great Basin region indicator (binary) & NIFMID & -- \\
\hline reg_5 & California region indicator (binary) & NIFMID & -- \\
\hline reg_6 & Northwest region indicator (binary) & NIFMID & -- \\
\hline fy06 & $\begin{array}{l}\text { Fiscal year } 2006 \text { indicator (binary, omitted } \\
\text { reference category) }\end{array}$ & NIFMID & -- \\
\hline fy07 & Fiscal year 2007 indicator (binary) & NIFMID & -- \\
\hline fy08 & Fiscal year 2008 indicator (binary) & NIFMID & -- \\
\hline fy09 & Fisal year 2009 indicator (binary) & NIFMID & -- \\
\hline fy 10 & Fiscal year 2010 indicator (binary) & NIFMID & -- \\
\hline fyl1 & Fiscal year 2011 indicator (binary) & NIFMID & -- \\
\hline \multicolumn{4}{|c|}{$\begin{array}{l}- \text { - indicates no change in the variable between ignition point and spatially descriptive model. } \\
\text { n/a indicates that the variable was not used in the ignition point model. } \\
\text { Data sources: FFIS - Foundation Financial Information System, which is being replaced by the Financial Management } \\
\text { Modernization Initiative (FMMI), available at http://info.fmmi.usda.gov/, accessed 9/3/2013. NIFMID - National } \\
\text { Interagency Fire Management Integrated Database, maintained at the USDA National Information Technology Center } \\
\text { in Kansas City, MO; NIFMID variables are self-reported by managers for each wildfire. NIFC FTP - available at } \\
\text { ftp://ftp.nifc.gov/Incident_Specific Data/, accessed 7/24/2013; WFDSS - Wildland Fire Decision Support System } \\
\text { databases available at http://wfdss.usgs.gov/wfdss/WFDSS_Data_Downloads.shtml, accessed 7/24/2013; LANDFIRE } \\
\text { - version 1.2.0 available at http://www.landfire.gov/lf_120.php, accessed 7/24/2013. }\end{array}$} \\
\hline
\end{tabular}

Preliminary results suggest that spatial heterogeneity of geographic and landscape characteristics affect suppression expenditures. In particular, the spatial pattern of surface fuels, protection designation (e.g., Wilderness Areas), land ownership, and housing values are significant predictors of expenditures. Further, the temporal pattern of fire weather and fuel moisture conditions is an important predictor of expenditures. The spatially descriptive model also improves prediction accuracy and 
model fit as compared with analogous models based on ignition-point characteristics. Table 2 compares the size of the standardized residuals (in standard deviation, or s.d., units) in the spatial/temporal model to those in the comparable ignition-point model.

Table 2. Comparison of standardized prediction errors between spatial/temporal model and ignition-point model

\begin{tabular}{ccc}
\hline Size of standardized residual & $\begin{array}{c}\text { Spatial model } \\
\text { frequency }\end{array}$ & $\begin{array}{c}\text { Ignition-point model } \\
\text { frequency }\end{array}$ \\
<= 1 s.d. & 104 & 94 \\
1 - 2 s.d. & 101 & 77 \\
2 - 3 s.d. & 87 & 69 \\
$>4$ s.d & $\underline{114}$ & $\underline{166}$ \\
All obs. & 406 & 406 \\
\hline
\end{tabular}

An immediate use of the spatially and temporally descriptive expenditure model is to improve the accuracy of expenditure predictions when the final burned area is known. For example, after-season reviews of fire-specific expenditures can be compared to predicted expenditures using the final fire perimeter and the spatial/temporal expenditure model. The results indicate that the modest improvements in prediction accuracy can lead to more reliable comparisons in the future.

The model can also be used to improve the functionality of decision support tools that include predictions of total incident expenditures. In the Wildland Fire Decision Support System (WFDSS), the ignition-point expenditure model is currently used to provide information about expected expenditures for an incident under given conditions (Noonan-Wright et al. 2011). The spatially and temporally explicit model may yield more nuanced information about expenditures because it can, in theory, be paired with fire models in WFDSS that result in predicted fire perimeters. For example, the expenditure model can be paired with fire spread models to generate spatially explicit expected expenditure maps. Such an application would leverage variations in fire behaviour generated by the fire spread model (which determines the size and areal extent of the fire), as well as spatial and temporal variations in characteristics that are related to expenditures. As risk management becomes a greater focus of wildfire management, risk-based expenditure information may assist managers in making strategic decisions during a fire incident.

Incorporating spatially descriptive data can provide richer information about how expenditures are affected by alternative land management scenarios. Planning and prioritizing the treatment of hazardous fuels to affect future fire behaviour may incorporate impacts on expected suppression expenditures (Fitch et al. 2013; Thompson et al. 2013). The spatial/temporal expenditure model could provide greater detail about how changes in fire behaviour relate to expenditures. For example, hazardous fuel treatments may not necessarily affect the expected number of ignitions or number of large fires in a given season, but could affect the spatial pattern of where fires are likely to burn. Ignition-point models of expenditures currently in use (e.g., in Thompson et al. 2013) only account for changes in fire size. But fuel treatments are an inherently spatial endeavour, and the location and pattern of treatments may have impacts on wildfire management that extend beyond changes in final fire size. Understanding the magnitude of any potential suppression cost trade-offs can assist managers in determining whether such investments are worth the cost.

In summary, spatially and temporally descriptive models of wildfire management expenditures show promise for improving predictions of expenditures and providing nuanced information for decision support and land management planning. Accounting for heterogeneity of characteristics in space and over time improves the fit and predictive power of wildfire expenditure models, and are readily adaptable to spatially explicit fire modelling tools. The models investigated in this paper are limited 
by the fact that they use relatively coarse geospatial data, and do not explicitly model how the progression of fire relates to expenditures. Future research using time-series panel data and finer scale geographic data may help alleviate these limitations.

\section{References}

Abatzoglou, J.T., 2013. Development of gridded surface meteorological data for ecological applications and modelling. International Journal of Climatology 33,121-131.

Fitch, R.A.,, Kim, Y-S., Waltz, A.E.M., 2013. Forest restoration treatments: their effect on wildland fire suppression costs. Northern Arizona University, Ecological Restoration Institute - Issues in Forest Restoration. Available at: http://library.eri.nau.edu/gsdl/collect/erilibra/index/assoc/D2013009.dir/doc.pdf, $\quad$ accessed April 15, 2014.

Gebert, K.M., Calkin, D.E., Yoder, J., 2007. Estimating suppression expenditures for individual large wildland fires. Western Journal of Applied Forestry 22, 188-196.

Gude, P.H., Jones, K., Rasker, R., Greenwood, M.C., 2013. Evidence for the effect of homes on wildfire suppression costs. International Journal of Wildland Fire 22, 537-548.

Hand, M.S., Gebert, K.M., Liang, J., Calkin, D.E., Thompson, M.P., Zhou, M., 2014. Economics of wildfire management: the development and application of suppression expenditure models. Springer Briefs in Fire, Springer, New York.

Liang, J., Calkin, D.E., Gebert, K.M., Venn, T.J., Silverstein, R.P., 2008. Factors influencing large wildland fire suppression expenditures. International Journal of Wildland Fire 17, 650-659.

Noonan-Wright, E., Opperman, T.S., Finney, M.A., Zimmerman, T., Seli, R.C., Elenze, L.M., Calkin, D.E., Fiedler, J.R., 2011. Developing the U.S. wildland fire decision support system. Journal of Combustion 2011 (Article ID 168473), 14pp.

Preisler, H.K., Westerling, A.L., Gebert, K.M., Munoz-Arriola, F., Holmes, T.P., 2011. Spatially explicit forecasts of large wildland fire probability and suppression costs for California. International Journal of Wildland Fire 20, 508-517.

Thompson, M.P., Vaillant, N.M., Haas, J.R., Gebert, K.M., Stockmann, K.D., 2013c. Quantifying the potential impacts of fuel treatments on wildfire suppression costs. Journal of Forestry 111, 4958.

Yoder, J., Gebert, K.M., 2012. An econometric model for ex ante prediction of wildfire suppression costs. Journal of Forest Economics 18, 76-89. 